MARTIW MARIETIA

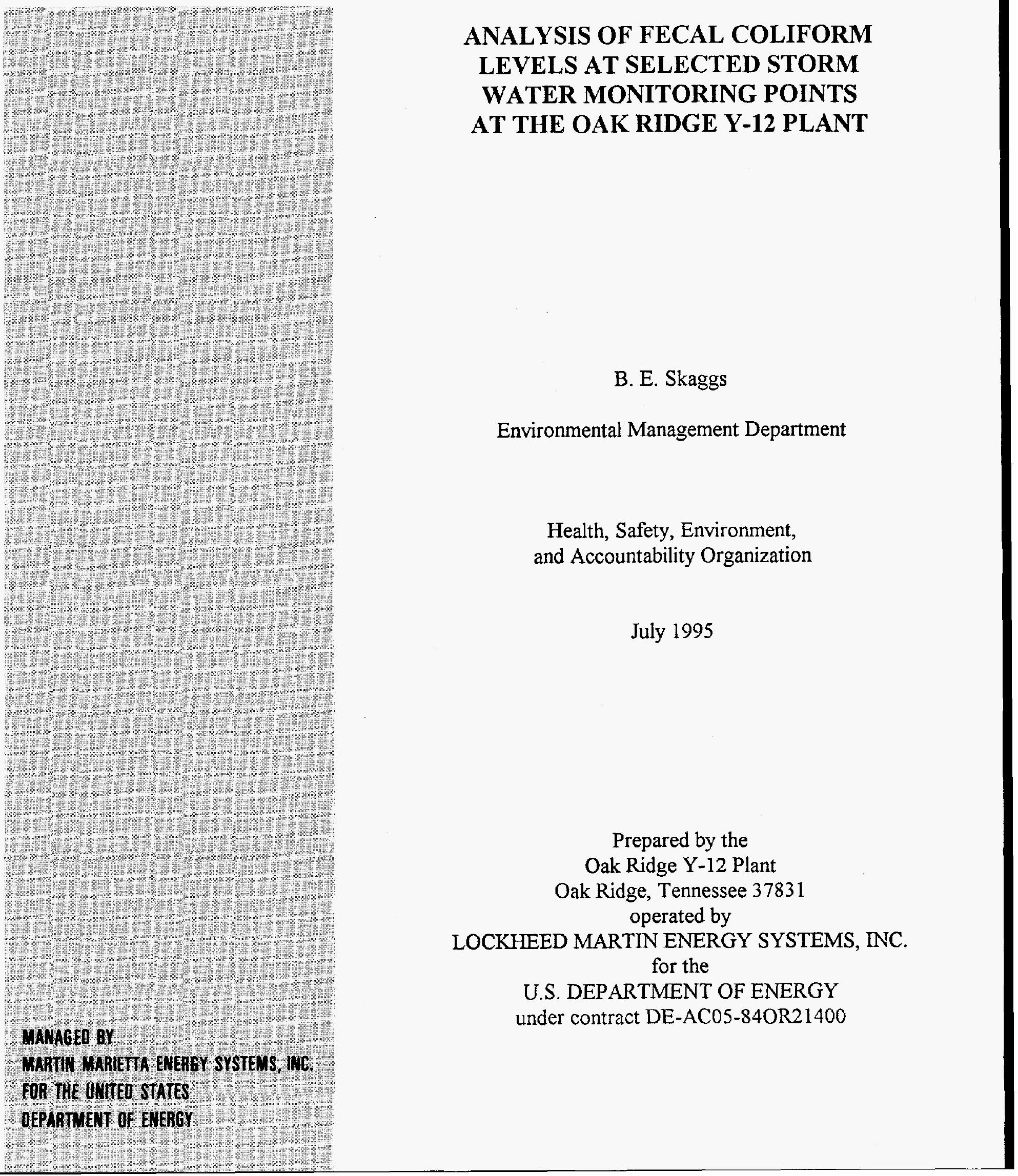

Health, Safety, Environment, and Accountability Organization

July 1995

\section{RECFIVED \\ NoV 171995 \\ OSTI \\ Y/TS-1374}




\title{
ANALYSIS OF FECAL COLIFORM LEVELS AT SELECTED STORM WATER MONITORING POINTS AT THE OAK RIDGE Y-12 PLANT
}

\author{
B. E. Skaggs \\ Environmental Management Department
}

Health, Safety, Environment, and Accountability Organization

July 1995

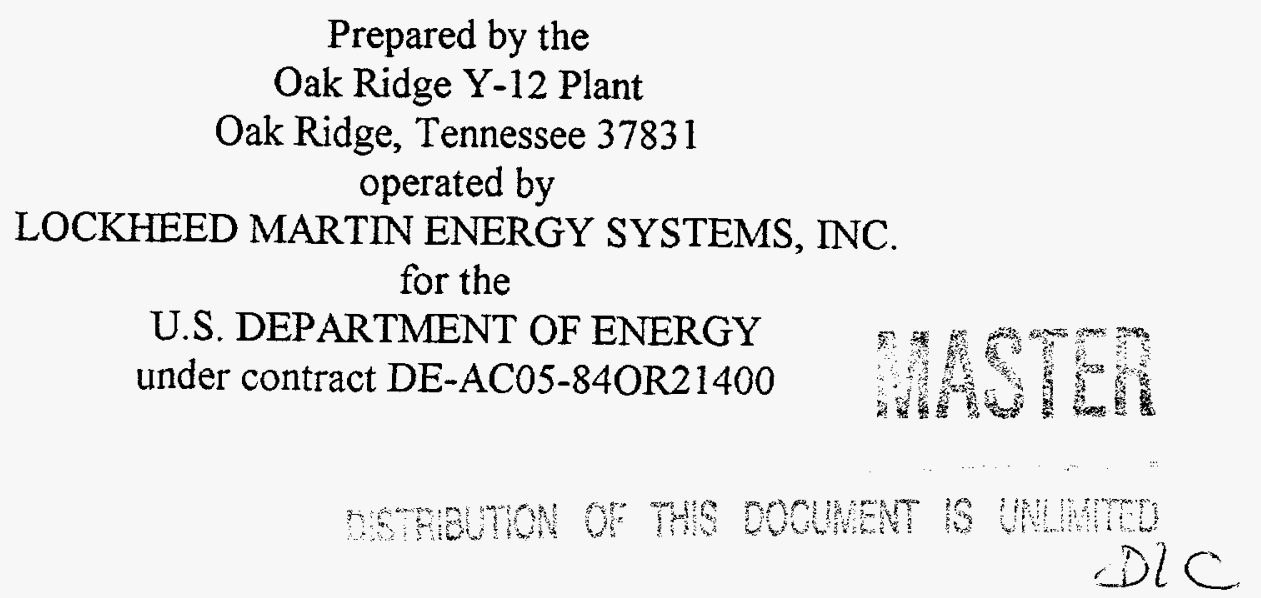




\section{DISCLAIMER}

This report was prepared as an account of work sponsored by an agency of the United States Government. Neither the United States Government nor any agency thereof, nor any of their employees, make any warranty, express or implied, or assumes any legal liability or responsibility for the accuracy, completeness, or usefulness of any information, apparatus, product, or process disclosed, or represents that its use would not infringe privately owned rights. Reference herein to any specific commercial product, process, or service by trade name, trademark, manufacturer, or otherwise does not necessarily constitute or imply its endorsement, recommendation, or favoring by the United States Government or any agency thereof. The views and opinions of authors expressed herein do not necessar. ily state or reflect those of the United States Government or any agency thereof. 


\section{DISCLAIMER}

Portions of this document may be illegible electronic image products. Images are produced from the best available original document. 


\section{Introduction}

The Environmental Protection Agency staff published the final storm water regulation on November 16, 1990. The storm water regulation is included in the National Pollutant Discharge Elimination System (NPDES) regulations. It specifies the permit application requirements for certain storm water discharges such as industrial activity or municipal separate storm sewers serving populations of 100,000 or greater. Storm water discharge associated with industrial activity is discharge from any conveyance used for collecting and conveying storm water that is directly related to manufacturing, processing, or raw material storage areas at an industrial plant. Quantitative testing data is required for these discharges.

An individual storm water permit application was completed and submitted to Tennessee Department of Environment and Conservation (TDEC) personnel in October 1992. After reviewing this data in the permit application, TDEC personnel expressed concern with the fecal coliform levels at many of the outfalls. The 1995 NPDES Permit (Part III-N, page 44) requires that an investigation be conducted to determine the validity of this data. If the fecal coliform data is valid, the permit requires that a report be submitted indicating possible causes and proposed corrective actions.

\section{Data Analysis}

Several sets of data were reviewed by Y-12 Plant personnel to identify elevated values for fecal coliform. For the purpose of this investigation, an "elevated value" was determined to be a value greater than the water quality standard for fecal coliform in each particular stream. The following data sets were reviewed: (1) analytical data supplied as part of the 1992 storm water permit application for the Oak Ridge Y-12 Plant, (2) data collected as a part of the Fecal Coliform Special Study conducted at the Y-12 Plant, (3) data collected as part of the Y-12 Plant Environmental Surveillance Project No. 1103, (4) data supplied as part of the NPDES permit application for the Oak Ridge National Laboratory, and (5) data for selected monitoring points at the K-25 Site.

\section{Fecal Coliform Special Study}

During May and June 1995, sampling for fecal coliform was performed at East Fork Poplar Creek (EFPC) in-stream locations. Three locations above Lake Reality (Outfall 200, Monitoring Station 8 , and the inlet to Lake Reality) and one below Lake Reality (Monitoring Station 17) were selected for this study. Grab samples were taken daily at each location for a period of two weeks. The purpose of this study was to provide a comparison of the mean values for coliform to the General Water Quality Criteria for the recreational use classification. This data is provided in Appendix A. In general, the data demonstrates that the stream conforms to the recreational use criteria of 200 colonies per $100 \mathrm{~mL}$ except during wet conditions. This could be an indication of exfiltration in the lines or overflow at cross-connections of wastewater from the sanitary sewer collection system to the storm drain system. 


\section{Environmental Surveillance Project No. 1103}

Since June 1993, 17 locations which reported elevated fecal values in the 1992 storm water permit application were resampled during wet and dry events. A project plan has been developed and implemented and is included as Appendix B. The data obtained from monitoring conducted under the plan is presented in Appendix C. In general, this data is lower than the data included in the permit application; however, the data indicates that values are elevated during wet weather conditions.

\section{Locations with Elevated Values}

Sampling at the following storm water outfalls which discharge to EFPC resulted in values greater than the recreational water quality standard for coliform in individual samples in EFPC: 002, 003, $006,007,011,014,017,045,046,057,062,086,110$, and 200.

Sampling at the following outfalls and monitoring points on Bear Creek or Bear Creek tributaries resulted in values greater than the recreational water quality standard for coliform in individual samples in Bear Creek: S01, S02, S03, S04, S05, S06, S07, S08, S09, S10, S11, S12, S13, and S14.

Sampling at the following outfalls and monitoring points resulted in values greater than 1,000 colonies per $100 \mathrm{~mL}$; these points are located along tributaries of the Clinch River: S15, S16, S17, S18, S20, and S21.

\section{Quality Assurance/Quality Control}

Samples were taken at random points along the Y-12 Plant sanitary sewer collection system to determine typical values of fecal coliform in raw sewage. This data was compared to values of fecal coliform found in the storm water permit application. Fecal coliform values for raw sewage ranged from 125,000 to 547,000 colonies per $100 \mathrm{~mL}$. The values listed in the storm water permit application ranged from $<1$ to 200,000 colonies per $100 \mathrm{~mL}$. These values can be found in Appendix D. In most instances, the storm water samples did not exhibit elevated values for fecal coliform as compared to typical values for raw sewage.

In order to evaluate the analytical techniques used in the laboratory, samples were split and taken to two different laboratories; and a comparison of the resulting data was made. The two laboratories provided consistent results. Field blanks taken during this sampling event revealed that proper sampling techniques were successful in preventing contamination of samples. Therefore, it is believed that sampling techniques and analysis are providing reliable results. Tabular data from this analysis is presented in Appendix E. 


\section{Possible Causes}

As indicated in the Permit Rationale Section of the NPDES Permit, some storm water outfalls are located near to, or cross, sanitary sewer lines. Elevated levels at these outfalls could indicate a local break in the sanitary sewer system. However, of the outfalls with elevated values, only five are in close proximity to sanitary sewer lines: 007, 014, 045, 110, and 200.

The Y-12 Plant is underlaid with an old and extensive system of storm drains and sanitary sewer collection lines. Breaks and blockages have occurred over recent years and have been quickly repaired; however, the incidents serve as an indication of the condition of the existing systems. The August 1993 report, "Y-12 Plant Sanitary Sewer Collection System Flow Study," provides information on the deficiencies of the sanitary collection system and addresses the increase in flow during major rain events. This increased flow is attributed to inflow and infiltration. Additionally, it is known that cross-connections exist between storm and sanitary sewers. Data collected during wet and dry weather conditions is presented in Appendices $\mathrm{A}$ and $\mathrm{C}$. The data shows an increase in concentrations of fecal coliform during wet weather conditions, even in storm drains at locations not immediately adjacent to sanitary sewers. Exfiltration from sewer lines has possibly migrated to enter at joints in the storm drains, and is probably the primary contributor to storm drains not immediately adjacent to sanitary sewers.

Because some of the storm water monitoring points are located in nonindustrialized areas, it is believed that some of the elevated values for fecal coliform are primarily due to the wildlife present in the area. Fecal coliform data from similar locations at the Oak Ridge National Laboratory range from 24 to $>6,000$ colonies per $100 \mathrm{~mL}$, while data from similar locations at the $\mathrm{K}-25$ Site range from 1 to 11,000 colonies per $100 \mathrm{~mL}$. Therefore, it is possible that wildlife is contributing to the fecal coliform values in nonindustrialized areas of the Y-12 Plant site. This would also be true for storm water outfalls along the south bank of EFPC which would be impacted by runoff from Chestnut Ridge.

\section{Proposed Actions}

The Y-12 Plant Sanitary Sewer Upgrade (SSU) line item project is an integral part of the effort to reduce fecal coliform levels in EFPC. The SSU project is intended to reduce the potential for blockages and back-ups of wastewater in the sanitary sewer system which could result in overflows of sewerage to EFPC. More than 250 manhole deficiencies and 11,900 feet of sewer line are scheduled to be repaired or replaced. Currently the Y-12 Plant sewer system flow increases in excess of 100 percent during rainfall events as a result of inflow and infiltration. The same sewer line deficiencies which could allow inflow and infiltration may also be conducive to exfiltration of sewerage into the surrounding soil, groundwater, and EFPC drainage area.

Sources of infiltration and/or exfiltration include deteriorated lines, joint separations, and manhole deficiencies. Selected lines and manholes will be rehabilitated through replacement and slip-lining. Sources of inflow, including cross-connections, roof drains, and deficient manhole covers, will 
also be addressed under this project. Some roof drains have already been rerouted to the storm sewer, and activities have been initiated to identify and reroute any remaining roof drains through normal maintenance activities. Another component of the SSU project is to replace the force main serving the west end of the Y-12 Plant. The force main has had recent failures that could have contributed to the fecal coliform levels in EFPC.

The SSU project is currently scheduled to begin video surveying of the entire collection system in August 1995. Upon completion of the video work, tentatively scheduled for fall 1995, detail design work of the line repair/replacement will be initiated. Actual construction of line rehabilitation work is presently scheduled to begin in August 1996 and be completed in August 1997. Work under this proposed schedule is contingent on availability of funds.

Actions will be taken to eliminate the sanitary sewer line at the East Pistol Range near Outfall 7. Because values for fecal coliform have been elevated at Outfall 7, the sanitary sewer line will be closed or eliminated to remove a potential source of contamination. It is believed that this sanitary sewer line is cross-connected or leaking.

Fecal coliform monitoring will continue to evaluate possible sources and will be conducted as detailed in the Storm Water Pollution Prevention Plan. The NPDES Permit requires a minimum of 25 storm water characterizations each year. Sampling may be expanded, if necessary, as sources of fecal coliform in storm water continue to be investigated. 


\section{APPENDIX A}

Data

Fecal Coliform Special Study

\begin{tabular}{|c|c|c|c|}
\hline Date & Weather & $\begin{array}{l}\text { Monitoring } \\
\text { Point }\end{array}$ & $\begin{array}{c}\text { Fecal Coliform, } \\
\text { co. } / 100 \mathrm{~mL}\end{array}$ \\
\hline $5 / 22 / 95$ & Dry & Station 17 & 270 \\
\hline $5 / 22 / 95$ & Dry & Lake Reality Inlet & 77 \\
\hline $5 / 22 / 95$ & Dry & Station 8 & 24 \\
\hline $5 / 22 / 95$ & Dry & Outfall 200 & 2 \\
\hline $5 / 23 / 95$ & Dry & Station 17 & 280 \\
\hline $5 / 23 / 95$ & Dry & Lake Reality Inlet & 42 \\
\hline $5 / 23 / 95$ & Dry & Station 8 & 23 \\
\hline $5 / 23 / 95$ & Dry & Outfall 200 & 1 \\
\hline $5 / 24 / 95$ & Dry & Station 17 & 88 \\
\hline $5 / 24 / 95$ & Dry & Lake Reality Inlet & 62 \\
\hline $5 / 24 / 95$ & Dry & Station 8 & 38 \\
\hline $5 / 24 / 95$ & Dry & Outfall 200 & 1 \\
\hline $5 / 25 / 95$ & Dry & Station 17 & 92 \\
\hline $5 / 25 / 95$ & Dry & Lake Reality Inlet & 39 \\
\hline $5 / 25 / 95$ & Dry & Station 8 & 22 \\
\hline $5 / 25 / 95$ & Dry & Outfall 200 & 1 \\
\hline $5 / 26 / 95$ & Dry & Station 17 & 50 \\
\hline $5 / 26 / 95$ & Dry & Lake Reality Inlet & 20 \\
\hline $5 / 26 / 95$ & Dry & Station 8 & 48 \\
\hline $5 / 26 / 95$ & Dry & Outfall 200 & 1 \\
\hline $5 / 30 / 95$ & Dry & Station 17 & 78 \\
\hline $5 / 30 / 95$ & Dry & Lake Reality Inlet & 77 \\
\hline $5 / 30 / 95$ & Dry & Station 8 & 120 \\
\hline $5 / 30 / 95$ & Dry & Outfall 200 & 150 \\
\hline $5 / 31 / 95$ & Dry & Station 17 & 80 \\
\hline $5 / 31 / 95$ & Dry & Lake Reality Inlet & 87 \\
\hline $5 / 31 / 95$ & Dry & Station 8 & 240 \\
\hline $5 / 31 / 95$ & Dry & Outfall 200 & 52 \\
\hline $6 / 1 / 95$ & Dry & Station 17 & 60 \\
\hline $6 / 1 / 95$ & Dry & Lake Reality Inlet & 150 \\
\hline $6 / 1 / 95$ & Dry & Station 8 & 250 \\
\hline $6 / 1 / 95$ & Dry & Outfall 200 & 94 \\
\hline $6 / 2 / 95$ & Wet & Station 17 & 4,400 \\
\hline $6 / 2 / 95$ & Wet & Lake Reality Inlet & 16,000 \\
\hline $6 / 2 / 95$ & Wet & Station 8 & 9,200 \\
\hline $6 / 2 / 95$ & Wet & Outfall 200 & 7,700 \\
\hline $6 / 5 / 95$ & Dry & Station 17 & 1,000 \\
\hline $6 / 5 / 95$ & Dry & Lake Reality Inlet & 80 \\
\hline $6 / 5 / 95$ & Dry & Station 8 & 150 \\
\hline $6 / 5 / 95$ & Dry & Outfall 200 & 19 \\
\hline
\end{tabular}




\title{
APPENDIX B \\ Y-12 PLANT ENVIRONMENTAL SURVEILLANCE PROJECT ACTION PLAN
}

\author{
PROJECT NO. 1103
}

\section{Project History}

The Environmental Protection Agency (EPA) staff published the final storm water regulation on November 16, 1990. The storm water regulation is included in the National Pollutant Discharge Elimination System (NPDES) regulations. It deals with permit application requirements for certain storm water discharges such as industrial activity or municipal separate storm water sewers serving populations of 100,000 or greater. Storm water discharge associated with industrial activity is discharge from any conveyance used for collecting and conveying storm water that is directly related to manufacturing, processing, or raw material storage areas at an industrial plant. Quantitative testing data is required for these discharges. It is to be reported on EPA Form 2F.

An initial storm water permit application was completed and submitted to Tennessee Department of Environment and Conservation (TDEC) personnel in October 1992. After reviewing this data, TDEC personnel expressed concern with the fecal coliform levels at many of the outfalls. The 1995 NPDES Permit (Part III-N, page 44) requires that an investigation be conducted to determine the validity of this data. If the fecal coliform data is valid, the permit requires that a report be submitted indicating possible causes and proposed corrective actions.

\section{Project Objective}

The objective of the project is to determine the validity of the fecal coliform data obtained during the initial storm water characterization.

\section{Project Description}

Sampling will be done by obtaining a grab sample at each of these outfalls during one dry weather event and sometime during one storm event. Storm event sampling will be performed if the storm event occurs after 72 hours of less than 0.1 inches of precipitation. The storm event must be at least 0.1 inches. Where feasible, the variance in the duration of the event and the total rainfall of the event should not exceed 50 percent from the average or median rainfall event in this area. According to Scientific Application International Corporation (SAIC), for the Central United States Rain Zone (which contains East Tennessee) an average rainfall event has a duration of 9.2 hours and a magnitude of 0.62 inches. This translates to a rainfall that has a magnitude between 0.31 and 0.93 inches with a duration between 4.6 and 13.8 hours. Dry weather sampling should also take place only after 72 hours of less than 0.1 inches of precipitation. 
Grab samples should include the fecal coliform analysis obtained by requesting FCOLI and using one, sterile $200-\mathrm{mL}$ plastic container for collection. Samples should be taken in duplicate in sets of five. One bottle of each sample is to be delivered to the Y-12 Plant Environmental Laboratory at Building 9769. The second bottle is to be delivered to the K-25 Site Analytical Laboratory. Due to the very short holding time associated with this analysis ( 6 hours), laboratory personnel should be contacted to verify laboratory capacity status before sampling occurs. The outfalls and monitoring points presented in Table 1 are to be sampled.

Table 1. Storm Water Outfalls and Monitoring Points to be Sampled Under the Environmental Surveillance Project No. 1103

\begin{tabular}{|c|c|}
\hline Outfall/Monitoring Point & Description \\
\hline 002 & 48-inch reinforced concrete pipe outfall to EFPC \\
\hline 004 & 54-inch corrugated metal pipe outfall to EFPC \\
\hline 006 & 42-inch corrugated metal pipe outfall to EFPC \\
\hline 007 & 24-inch reinforced concrete pipe outfall to EFPC \\
\hline 014 & 36-inch reinforced concrete pipe outfall to EFPC \\
\hline 046 & 6-inch terra-cotta tile outfall to EFPC \\
\hline 058 & 36-inch terra-cotta tile outfall to EFPC \\
\hline S01 & 36-inch reinforced concrete pipe outfall to BC \\
\hline S02 & 48-inch corrugated metal pipe outfall to BC \\
\hline S03 & 18-inch reinforced concrete pipe outfall to BC \\
\hline S04 & 18-inch reinforced concrete pipe outfall to BC \\
\hline S09 & In-stream monitoring point in Tributary 4 \\
\hline S10 & In-stream monitoring point in Tributary 5 \\
\hline S11 & In-stream monitoring point in Tributary 6 \\
\hline S16 & East Borrow Area Sedimentation Basin Discharge \\
\hline S20 & 48 corrugated metal pipe outfall \\
\hline
\end{tabular}

$\mathrm{BC}=$ Bear Creek

$\mathrm{EFPC}=$ East Fork Poplar Creek 


\section{Quality Control}

Laboratory water should be taken to the field and poured into sampling containers as a field blank with every sampling event. All samples will be kept under chain of custody at all times according to Procedure ESP-500. All equipment will be decontaminated between samples according to ESP-900. All grab samples will be taken according to ESP-301-1. Sterile techniques should be strictly adhered to during sampling. Samples should be collected directly into the container and not transferred from another container.

\section{Safety Concerns}

The sampling technicians will wear safety glasses, gloves, and company clothing as the minimum personal protective equipment. Due to inclement weather conditions, sampling personnel should work in teams of at least two persons at all times.

\section{Data Management}

Data will be reviewed by Water Compliance Section personnel. The prescribed outfalls detailed by this plan were selected because at least one of the samples obtained during the original storm water sampling effort had a fecal coliform result of more than 10,000 colonies per $100 \mathrm{~mL}$. If no conclusions can be drawn from this new data, the sampling effort may be expanded. 


\section{APPENDIX C}

Fecal Coliform Data

Environmental Surveillance Project No. 1103

\begin{tabular}{|c|c|c|c|c|}
\hline Date & Weather & $\begin{array}{c}\text { Outfall or } \\
\text { Monitoring } \\
\text { Point }\end{array}$ & $\begin{array}{c}\text { Fecal } \\
\text { Coliform, } \\
\text { co } / 100 \mathrm{~mL}\end{array}$ & Notes \\
\hline $6 / 25 / 93$ & Dry & 002 & 520 & \\
\hline $6 / 25 / 93$ & Dry & 004 & 130 & \\
\hline $6 / 25 / 93$ & Dry & 014 & 1 & \\
\hline $9 / 15 / 93$ & Wet & 002 & 20,000 & \\
\hline $9 / 15 / 93$ & Wet & 007 & 120,000 & Deer Near-by \\
\hline $9 / 15 / 93$ & Wet & 014 & 8,300 & \\
\hline $9 / 15 / 93$ & Wet & 046 & 3,500 & \\
\hline $12 / 2 / 93$ & Dry & S02 & 22 & \\
\hline $12 / 2 / 93$ & Dry & S09 & 96 & \\
\hline $2 / 16 / 94$ & Dry & $\mathrm{SO3}$ & 1 & \\
\hline $2 / 16 / 94$ & Dry & S04 & 1 & \\
\hline $4 / 21 / 94$ & Dry & 046 & 1 & \\
\hline $4 / 21 / 94$ & Dry & 058 & 26 & \\
\hline $4 / 21 / 94$ & Dry & S11 & 14 & \\
\hline $7 / 27 / 94$ & Wet & S02 & 1,200 & \\
\hline $7 / 27 / 94$ & Wet & S09 & 720 & \\
\hline $7 / 27 / 94$ & Wet & S09 & 720 & \\
\hline $7 / 27 / 94$ & Wet & S11 & 410 & \\
\hline $2 / 16 / 95$ & Dry & S04 & 1 & \\
\hline $6 / 7 / 95$ & Wet & 014 & 9,500 & \\
\hline $6 / 7 / 95$ & Wet & 046 & 1 & \\
\hline $6 / 7 / 95$ & Wet & SOI & 5,100 & \\
\hline $6 / 7 / 95$ & Wet & S02 & 1,200 & \\
\hline $6 / 7 / 95$ & Wet & $\mathrm{SO3}$ & 7,100 & \\
\hline $6 / 7 / 95$ & Wet & S04 & 8,100 & \\
\hline $6 / 7 / 95$ & Wet & S11 & 1,400 & \\
\hline $6 / 15 / 95$ & Dry & 002 & 110 & \\
\hline $6 / 15 / 95$ & Dry & 004 & 130 & \\
\hline $6 / 15 / 95$ & Dry & 014 & 1 & \\
\hline $6 / 26 / 95$ & Dry & 002 & 82 & \\
\hline $6 / 26 / 95$ & Dry & 004 & 80 & \\
\hline $6 / 26 / 95$ & Dry & 014 & 1 & \\
\hline $6 / 26 / 95$ & Dry & $\mathrm{S} 02$ & 470 & \\
\hline $6 / 26 / 95$ & Dry & S09 & 190 & \\
\hline
\end{tabular}




\section{APPENDIX D}

Fecal Coliform Data

Sanitary Sewer System Monitoring

\begin{tabular}{|l|l|r|}
\hline Date & \multicolumn{1}{|c|}{ Location } & $\begin{array}{c}\text { Fecal } \\
\text { Coliform, } \\
\text { co./100 } \mathbf{~ m L}\end{array}$ \\
\hline $5 / 17 / 95$ & East End Sanitary Sewer Monitoring Station & 125,000 \\
\hline $5 / 18 / 95$ & East End Sanitary Sewer Monitoring Station & 407,000 \\
\hline $5 / 18 / 95$ & Lift Station southeast of Building $9204-3$ & 547,000 \\
\hline
\end{tabular}




\section{APPENDIX E}

Fecal Coliform Data

Laboratory Comparison Study

\begin{tabular}{|r|r|l|r|r|}
\hline Outfall & Date & Weather & Y-12 Lab & K-25 Lab \\
\hline 002 & $6 / 25 / 93$ & Sunny & 520 & 367 \\
\hline 004 & $6 / 25 / 93$ & Sunny & 130 & 240 \\
\hline 014 & $6 / 25 / 93$ & Sunny & $<1$ & $<1$ \\
\hline 002 & $9 / 15 / 93$ & Rain & 20,000 & TNTC \\
\hline 007 & $9 / 15 / 93$ & Rain & 120,000 & TNTC \\
\hline 014 & $9 / 15 / 93$ & Rain & 8,300 & TNTC \\
\hline 046 & $9 / 15 / 93$ & Rain & $>3,500$ & TNTC \\
\hline S03 & $2 / 16 / 94$ & Sunny & $<1$ & 20 \\
\hline S04 & $2 / 16 / 94$ & Sunny & $<1$ & 26 \\
\hline S20 & $2 / 16 / 94$ & Sunny & 18 & 14 \\
\hline 046 & $4 / 21 / 94$ & Sunny & $<1$ & 1,137 \\
\hline 058 & $4 / 21 / 94$ & Sunny & 26 & 18 \\
\hline S11 & $4 / 21 / 94$ & Sunny & 14 & 31 \\
\hline
\end{tabular}




\section{APPENDIX F}

Fecal Coliform Data

1992 National Pollutant Discharge Elimination System Storm Water Permit Application

\begin{tabular}{|c|c|c|}
\hline & \multicolumn{2}{|c|}{ Fecal Coliform (co./100 mL) } \\
\hline Outfall No. & \begin{tabular}{|l|l} 
Max. Daily & \\
\end{tabular} & Long-Term Average \\
\hline 002 & 130 & $<83.67$ \\
\hline 003 & 7,840 & 7,840 \\
\hline 006 & TNTC & $>4000$ \\
\hline 007 & 165,000 & 165,000 \\
\hline 011 & 1,500 & 1,100 \\
\hline 014 & 160 & 79 \\
\hline 015 & 36 & 36 \\
\hline 017 & 2,020 & 81 \\
\hline 018 & 57 & $<1$ \\
\hline 021 & 42 & $<21.5$ \\
\hline 032 & 8,000 & 8,000 \\
\hline 033 & 20 & 20 \\
\hline 041 & 250 & 40 \\
\hline 044 & 100 & 100 \\
\hline 045 & 34,000 & 34,000 \\
\hline 057 & 640 & 300 \\
\hline 062 & 630 & 630 \\
\hline 064 & 217 & 162 \\
\hline 086 & 960 & 960 \\
\hline 088 & 320 & $<107$ \\
\hline 098 & 446 & 87 \\
\hline 110 & 3,800 & 3,800 \\
\hline 111 & 1,158 & 1,158 \\
\hline 114 & 300 & $<107$ \\
\hline S01 & 40,000 & 18,000 \\
\hline S02 & 9,000 & 9,000 \\
\hline SO3 & 27,000 & $<1$ \\
\hline SO4 & 30,000 & 30,000 \\
\hline S05 & 6,700 & 6,700 \\
\hline S06 & 1,800 & 1,400 \\
\hline S07 & 1,000 & 1,000 \\
\hline S08 & 1,300 & 30 \\
\hline S09 & 33,000 & 30,000 \\
\hline S10 & 10,000 & 2,000 \\
\hline SI1 & 35,000 & 35,000 \\
\hline $\mathrm{S} 12$ & 950 & 950 \\
\hline S13 & 1,000 & 1,000 \\
\hline SI4 & 9,000 & 9,000 \\
\hline $\mathrm{S} 15$ & 1,200 & 1,200 \\
\hline S16 & 200,000 & 200,000 \\
\hline $\mathrm{S17}$ & 234 & 234 \\
\hline
\end{tabular}




\section{APPENDIX F}

Fecal Coliform Data

1992 National Pollutant Discharge Elimination System Storm Water Permit Application

\begin{tabular}{|r|r|r|}
\hline & \multicolumn{2}{|c|}{ Fecal Coliform (co./100 mL) } \\
\hline Outfall No. & Max. Daily & Long-Term Average \\
\hline S18 & 1,226 & 1,226 \\
\hline S19 & 20 & 20 \\
\hline S20 & 68,000 & 68,000 \\
\hline S21 & 260 & 260 \\
\hline S22 & 57 & 57 \\
\hline TNTC $=$ Too Numerous To Count & \\
\hline
\end{tabular}

